\title{
Cheese whey recycling in traditional dairy food chain: effects of vinegar from whey in dairy cow nutrition
}

\author{
Giuseppe Lustrato, ${ }^{1}$ Elisabetta Salimei, ${ }^{2}$ Gabriele Alfano, ${ }^{1}$ Claudia Belli, ${ }^{1}$ Francesco Fantuz, ${ }^{3}$ \\ Luigi Grazia, ${ }^{4}$ Giancarlo Ranalli ${ }^{1}$ \\ ${ }^{1}$ Department of Bioscience and Territory, University of Molise, Pesche (IS); ${ }^{2}$ Department of \\ Agricultural, Environmental and Food Sciences, University of Molise, Campobasso; ${ }^{3}$ Department \\ of Environmental Sciences, University of Camerino; ${ }^{4}$ Department of Agri-food Protection and \\ Improvement, University of Bologna, Italy
}

\begin{abstract}
Selected yeast (Kluyveromyces marxianus Y102 strain) and an acetic acid bacterium (Acetobacter aceti, DSM-G3508 strain) were used as inocula respectively in cheese whey for alcoholic and acetic fermentations. The experimental tests were carried out at both laboratory and pilot plant $(20 \mathrm{~L}$ and $2000 \mathrm{~L}$ ) levels. The data from the trials (working period 28 days) show increased ethanol production,
\end{abstract}

Correspondence: Giancarlo Ranalli, DiBT, University of Molise, C.da Fonte Lappone, 86090 Pesche (IS), Italy. E-mail: ranalli@unimol.it

Key words: whey, microbial fermentation, recycling, traditional dairy chain, cow nutrition.

Acknowledgements and funding: the Authors acknowledge both Parco Scientifico Tecnologico (PST) Moliseinnovazione (Campobasso, Italy) for the financial support, and Centro di Ricerche Applicate alle Biotecnologie (CRAB, Avezzano, Italy) for providing bioreactors and technical support. Thanks are also addressed to Mr. D. Iacovantuono, Dr. C. Maglieri, R. Socci and Dr. A. Cappuccio for their precious cooperation.

Conference presentation: part of this paper was presented at the $3^{\text {rd }}$ International Conference on Acetic Acid Bacteria. Vinegar and Other products, 2012 Apr 17-20, Cordoba, Spain (http://www.uco.es/aab2012/).

Contributions: CB, GA, GL, LG, GR, whey sampling and yeast strains' characterization, isolation and identification, yeast and acetic acid bacteria inocula preparation, alcoholic and acetic fermentations in lab and plant bioreactors, acetic acid shelf life, statistical analysis; ES, FF, dairy ration formulation, experimental observations on milk production and composition, feeding particle size, and nutritional status of dairy cows, and data statistical processing. All authors shared discussion of the results and conclusions.

Conflict of interests: the authors declare no potential conflict of interests.

Received for publication: 26 July 2012.

Revision received: 28 November 2012.

Accepted for publication: 11 December 2012.

This work is licensed under a Creative Commons Attribution 3.0 License (by-nc 3.0).

(C) Copyright G. Lustrato et al., 2013

Licensee PAGEPress, Italy

Acetic Acid Bacteria 2013; 2(s1):e8

doi:10.4081/aab.2013.s1.e8 increased acetic acid yield, and greater fermentation stability with biomass recycling $\left(18.6 \mathrm{~g} \mathrm{~L}^{-1}\right)$. Batch and fed-batch fermentation tests resulted in increased and standardized alcoholic fermentation, and allowed acetic acid recovery (average lactose consumption 56\%, ethanol $6.7 \mathrm{~g} \mathrm{~L}^{-1} \mathrm{~d}^{-1}$ and acetic acid production $\left.4.35 \mathrm{~g} \mathrm{~L}^{-1} \mathrm{~d}^{-1}\right)$. The effects administration were then investigated on milk yield and composition, nutritional status of dairy cows and physical characteristics of total mixed ration (TMR). Twenty Holstein cows were divided into two groups; group $\mathrm{C}$, receiving the traditional TMR, and group W, receiving the TMR plus $10 \mathrm{~L}$ wheynegar. The dietary treatment, lasted 35 days, did not affect milk yield and composition except for the urea content, significantly lowered in group W. The selection of coarse $(<19$ $\mathrm{mm})$, medium $(8-19 \mathrm{~mm})$ and fine $(<8 \mathrm{~mm})$ dietary particles was not influenced by the wheynegar administration however a tendential lower selection against coarse particles was noted in W. The results highlight that microbial biotechnologies may significantly contribute to both the valorization of whey and the development of a stable nutrient recycling system as a ingredient in dairy cattle diet.

\section{Introduction}

The world production of cheese whey is estimated to be over $10^{8}$ tons per year yielding an important source of environmental pollution since approximately $10 \mathrm{~L}$ cheese whey is produced from $1 \mathrm{~kg}$ cheese. ${ }^{1}$ Cheese whey is usually considered as a high strength wastewater with biochemical oxygen demand (BOD) and chemical oxygen demand (COD) contents of approximately 50 and $80 \mathrm{~g} \mathrm{~L}^{-1}$, respectively. ${ }^{2-6}$ Therefore biological treatments of cheese whey (COD=70,000 ppm) by conventional aerobic activated sludge process would cost approx. 4-6 euro $\mathrm{m}^{-3}{ }^{7}$ More than $90 \%$ of the BOD in whey is due to lactose and because of this high BOD value, whey can disrupt the biological processes of wastewater treatment plants. In addition, the continuous discharge of whey onto land can endanger the chemical and physical structure of the soil, reduce crop yields and lead to serious groundwater pollution problems, thus making it a threat to human and animal health. ${ }^{8,9}$ For this reason, industrially developed countries have specific legislation governing the disposal of this pollutant effluent of the dairy industry.

Cheese whey, a liquid by-product of the cheese-making process, contains water and most of the milk water-soluble components (approximately 5\% lactose, $0.9 \%$ nitrogenous compounds, $0.8 \%$ minerals and small vitamin amounts). ${ }^{10-12}$ Due to its composition, cheese whey has been used for production of different chemicals such as organic acids (lactic, acetic), alcohol (ethanol), single cell protein, 
methane, and cheese whey powder. ${ }^{13}$ Moreover, the use of whey as a lactose source is limited and the interest toward whey proteins as additive to food products is developing. ${ }^{14}$ In Mediterranean countries where the dairy sector, cheese making-oriented, has a marked traditional character, whey is also used in animal feeding as dried, concentrated or liquid whey, for its nutritional value. In particular, the by-product of traditional cheese making can be profitably used in dairy cattle or swine feeding. ${ }^{15-17}$ However, safety, hygiene and shelf-life are major concerns on recycling liquid whey into animal diets. Further constraints in the utilization of fresh liquid whey are linked to high transportation costs of the bulky liquid and the low productivity of drying facilities. An alternative for whey recycling in traditional dairy chains is the bioconversion of lactose to ethanol, that would not only reduce the environmental impact of cheese making but would also provide ethanol, a valuable energy resource, and acetic acid. The production of acetic acid from whey is an attractive method to recycle community waste, with the double benefit of reducing the problems of waste disposal and environmental pollution due to the salts in the whey. ${ }^{18,19}$

Fermentation processes could exploit this cheese making by-product through the production of whey vinegar (wheynegar) suitable as a dietary source for ruminants, due to its stability joined to its palatability and nutritive value. Fiber-digesting rumen microbiota may in fact require ammonia or $\mathrm{CO}_{2}$, but also acetic and other acids are crucial nutrients in the rumen ecosystem. ${ }^{20}$

The study aims at investigating: i) the optimization of the ethanol, acetic acid and cell biomass yields; ii) the scaling-up of the process at the pilot plant scale; iii) the stability over the time (shelf life) of the fermented acetic product; iv) the study of the effects of wheynegar administration as a ingredient in dairy cattle diet.

\section{Materials and Methods}

\section{Whey sampling and bioreactor plants}

The laboratory-scale experiment conducted involved three sequential stages depending on the type of process applied: ethanol fermentation (stage 1), acetic fermentation (stage 2), dairy cow nutrition (stage $3)$.

Sweet cheese whey was obtained from a dairy industry (Parco Scientifico Tecnologico Molise Innovazione, Campobasso, Italy), and stored in $50 \mathrm{~kg}$ tanks at $-25^{\circ} \mathrm{C}$ until required, in a commercial freezing plant to reduce microbial and enzymatic degradation. When the whey was needed, a few containers were removed from the freezer and taken to the laboratory where they were thawed at room temperature. Table 1 shows the characteristics of the cheese whey used in the study. The analyses were performed according to the procedures described in the Standard Methods for the Examination of Water and Wastewater. ${ }^{21}$ The crude whey, non-deproteinized, non-diluted and non-sterilized, was used as the culture medium.

A 20 L working capacity bioreactor (Biostat C, B. Braun Biotech International, Melsungen, Germany) was used for the laboratory experiments. For the pilot plant experiments, two completely automated bioreactors of $200 \mathrm{~L}$ and $2000 \mathrm{~L}$, were adopted (Bioindustrie Mantovane s.r.l., Mantova, Italy). All bioreactors were equipped with controls for temperature, $\mathrm{pH}$, agitation speed and aeration rate.

\section{Isolation and identification of yeast strains}

For yeast sample enrichment, $5 \mathrm{~mL}$ of the crude whey samples were inoculated in $50 \mathrm{~mL}$ of sterilized malt extract broth containing $\left(\mathrm{g} \mathrm{L}^{-1}\right)$ : malt extract 17.0, peptone 3.0 and 0.1 chloramphenicol, and incubated at $25^{\circ} \mathrm{C}$ for $24 \mathrm{~h}$ under $180 \mathrm{rpm}$ constant shaking. After incubation, light microscopy was used to highlight the yeast cells in the media, and the

media containing yeast cells were used for yeast strain isolation. ${ }^{1,22}$

The yeast strains were isolated on spread plates of chloramphenicol glucose yeast extract agar (Oxoid, B01035M, Basingstoke, UK) containing $\left(\mathrm{g} \mathrm{L}^{-1}\right)$ yeast extract 5.0, glucose 20.0, chloramphenicol 0.1, agar 15.0 ; the plates were then incubated at $25^{\circ} \mathrm{C}$ for $72 \mathrm{~h}$. Colonies with distinct morphological differences were selected and purified by streaking solid yeast extract agar medium (Oxoid CM 0019, Basingstoke, UK) containing ( $\mathrm{g} \mathrm{L}^{-1}$ ) yeast extract 3.0, peptone 5.0 and agar 15.0. The purified isolates were stored on yeast extract agar slants at $4^{\circ} \mathrm{C}$. For yeast identification, physiological and biochemical characterization of isolates was performed on media and under incubation conditions according to traditional methods ${ }^{23}$ and also with API 20 C AUX test strips (BioMérieux Italia, Rome, Italy).

\section{Yeasts and acetic acid bacteria inocula}

The Kluyveromyces marxianus Y102 strains, isolated in this study and Acetobacter aceti DSM-3508 (DSMZ, Leibniz Institute DSMZGerman Collection of Microorganisms and Cell Cultures, Braunschweig, Germany) were respectively used for alcoholic and acetic fermentations. Stock cultures of yeast strains and acetic acid bacteria were maintained on yeast extract agar and glucose yeast extract agar slants, respectively and stored at $4^{\circ} \mathrm{C}$.

Inocula developments were carried out in two phases. In the first, one loopful of isolated yeast and acetic acid bacteria culture was separately transferred, to $20 \mathrm{~mL}$ sterile yeast extract broth or glucose yeast extract broth, in a $200 \mathrm{~mL}$ Erlenmeyer flask and incubated at $28^{\circ} \mathrm{C}$ for $24 \mathrm{~h}$ or and $32^{\circ} \mathrm{C}$ for $24 \mathrm{~h}$, respectively. In the second phase, $20 \mathrm{~mL}$ of each $24 \mathrm{~h}$ old inoculum was aseptically transferred to a $5000 \mathrm{~mL}$ Erlenmeyer flasks containing separately each $2000 \mathrm{~mL}$ fermentation media and submitted on rotary shaker at $200 \mathrm{rpm}$ for $24 \mathrm{~h}$. Before inoculating the bioreactors, aliquot of $10 \mathrm{~mL}$ were collected from each flasks and were submitted to chemical analyses and cell enumeration including a centrifugation at $12,000 \mathrm{~g}$ for $20 \mathrm{~min}$; then, the cells were harvested and biomass concentration were measured at $600 \mathrm{~nm}$ (Cole-Parmer, mod 115 VAC, Vernon Hills, IL, USA). The developed inoculum was aseptically transferred $(10 \% \mathrm{v} / \mathrm{v})$ to the lab bioreactor.

Alcoholic and acetic fermentation in both lab and pilot plants industrial bioreactors ethanol fermentation was carried out in fed-batch conditions and has been divided into 14 fermentation cycles. The first fermentation cycle of $18 \mathrm{~L}$ (working volume) of cheese whey, was performed into the bioreactor preventively sterilized at $121^{\circ} \mathrm{C}$ for $15 \mathrm{~min}$ and inoculated with Kluyveromyces marxianus Y102 10\% (v/v). After 48 $\mathrm{h}$ of ethanol fermentation, a replacement of $50 \% \mathrm{v} / \mathrm{v}$ of the fermented

Table 1. Composition of cheese whey.

\begin{tabular}{lc} 
Parameter & Value \\
Total solid (\%) & 6.5 \\
Protein (\%) & 0.75 \\
\hline Fat (\%) & 0.02 \\
$\mathrm{Ca}(\%)$ & 0.045 \\
\hline Phosphate $\left(\mathrm{mg} \mathrm{kg}^{-1}\right)$ & 649 \\
Potassium $\left(\mathrm{mg} \mathrm{kg}^{-1}\right)$ & 1485 \\
\hline Sodium $\left(\mathrm{mg} \mathrm{kg}^{-1}\right)$ & 528 \\
Lactose $\left(\mathrm{mg} \mathrm{L}^{-1}\right)$ & 23,700 \\
\hline pH & 4.0 \\
COD (mg L-1) & 62,000 \\
\hline BOD (mg L-1) & 45,000 \\
\hline COD, chemical oxygen demand; BOD, biochemical oxygen demand.
\end{tabular}


permeate was adopted: $9 \mathrm{~L}$ were unloaded and stored at $4^{\circ} \mathrm{C}$ until the acetic fermentation, and $9 \mathrm{~L}$ of fresh crude whey were loaded (Figure 1). This procedure was repeated 13 times until depletion of crude cheese whey. The fermentation parameters were: $32^{\circ} \mathrm{C}, \mathrm{pH} 4.0$, agitation at $350 \mathrm{rpm}$, airflow off. Subsequently, on $135 \mathrm{~L}$ of alcoholic fermented the acetic fermentation was carried out (stage 2). The acetic batch fermentations was carried out on $18.0 \mathrm{~L}$ alcoholic end-product, adding 10\% v/v of Acetobacter aceti DSM-3508 inoculum, temperature controlled at $32^{\circ} \mathrm{C}$, agitation at $250 \mathrm{rpm}$, airflow ratio $2: 1 \mathrm{vvm}$.

Three cycles of alcoholic and acetic fed-batch fermentations were performed, at large pilot plant scale, from $200 \mathrm{~L}$ to $2000 \mathrm{~L}$, under the same alcoholic and acetic laboratory conditions. The intermediate alcoholic and the last acetic acid effluents were stored in PVC tanks $\left(5 \times 1000 \mathrm{~L}\right.$ each) at $4^{\circ} \mathrm{C}$. Moreover, the stability of the alcoholic fermentation with a final biomass recycling, under fed-batch condition for 28 days, at $28^{\circ} \mathrm{C}$, was performed (Figure 1 and Table 2).

\section{Biomass recycling}

The technique used for biomass recycling on the alcoholic fermented effluent included a batch recovery of viable cells by soft mechanical filtration facilitate by vacuum pump; aliquot of effluents (10-50 L) were submitted on sterile cellulose paper in a filter support in PET device (Sartorius Stedim Biotech, Firenze, Italy); after the filtration the filters enriched of cell biomass on the surface were immediately submitted to a gentle agitation/vortex $5 \mathrm{~min}$, at $200 \mathrm{rpm}$, in $500 \mathrm{~mL}$ of sterile physiological solution $(0.8 \% \mathrm{NaCl}, \mathrm{pH} 7.0)$, and introduced in the influent 2 step fermentation (alcoholic phase).

\section{Whey protein concentrate recovery}

The retentate from the alcoholic fermentation was further concentrated in a falling film evaporator under vacuum ( $840 \mathrm{mbar}$ ), cooled to $36^{\circ} \mathrm{C}$ and then dried at an outlet $50^{\circ} \mathrm{C}$ in a spray-drier, $40 \mathrm{~kg} \mathrm{~h}^{-1}$ of a vaporized water (Anhydro Group, Soeborg, Denmark) with integrated fluid bed. The final whey protein concentrate (WPC) obtained was bagged by vacuum pump, into $0.5 \mathrm{~kg}$ bags.

\section{Acetic acid shelf-life on the fermented product}

The shelf-life on the final fermented product (acetic mixer) was carried out on broth samples after long term storage at room temperature, $4^{\circ} \mathrm{C}$ and $28^{\circ} \mathrm{C}$, as follow: total viable cell number of aerobic heterotrophic bacteria was evaluated in standard plate count agar at $37^{\circ} \mathrm{C}$ after 72 $\mathrm{h}$ of incubation; for yeast in YPD (Oxoid, Garbagnate (MI), Italy) at $28^{\circ} \mathrm{C}$, after $48 \mathrm{~h}$, respectively, for lactic acid bacteria in de Man, Rogosa, Sharpe (Difco, Detroit, MI, USA) at $37^{\circ} \mathrm{C}$ after $72 \mathrm{~h}$ and for coliforms in violet red bile agar (VRBA, Difco) $37^{\circ} \mathrm{C}$ after $48 \mathrm{~h}$. The quantitative determination of the total viable microflora was done on several samples by a traditional culture technique, on the basis of colony forming units (CFU) and expressed as $\log \mathrm{CFU} \mathrm{mL}^{-1}$. Ten-fold serial dilutions in $0.1 \%(\mathrm{w} / \mathrm{v})$ peptone water were carried out in triplicate in Petri dishes.

\section{Animals and diets}

According to applicable animal care protocols for feeding trials, twenty multiparous Holstein cows, housed in a free stall barn in
Centre-South Italy $\left(41^{\circ} 33^{\prime} 0^{\prime \prime} \mathrm{N}, 14^{\circ} 29^{\prime} 0^{\prime \prime} \mathrm{E}\right)$, were paired into two groups, ten subjects each, receiving either a daily total mixed ration (TMR) plus $10 \mathrm{~L}$ water per head (group C), or the TMR plus $10 \mathrm{~L}$ of wheynegar per head (group W). Cows averaged 183 days in milk (DIM) and produced $22.15 \mathrm{~kg}$ milk d $^{-1}$ with an average body condition score of 2.8 at the beginning of the trial. Cows' body condition was also scored, according to INRA, ${ }^{24}$ at the end of the trial.

The animals had free access to clean water. Chemical composition and analysis of TMR composition are reported in Table 3 . It has to be noted the poor microbial quality of the hays ( 2.35 million mould spore count $\mathrm{g}^{-1}$ ).

TMR was offered to produce 5\% refusals, in order to achieve the maximum dietary intake; wheynegar from the industrial bioreactor was gradually introduced in the ration $\mathrm{W}$ ( 5 days). The trial lasted 35 days; experimental relieves and samplings were carried out at 0,20 and 35 days of the trial.

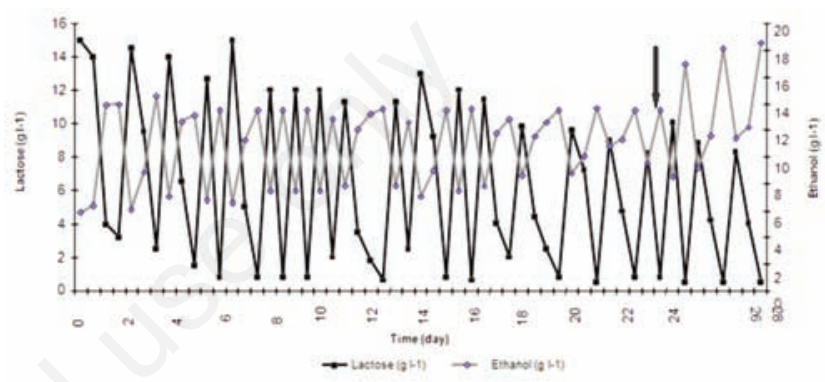

Figure 1. Fed-batch ethanol fermentation with yeast biomass recycle.

Table 3. Ingredients and chemical composition of total mixed ration.

\begin{tabular}{|c|c|}
\hline & dry matter \\
\hline \multicolumn{2}{|l|}{ Ingredients } \\
\hline Alfalfa hay, coarse & 170 \\
\hline Meadow hay, coarse poor quality & 293 \\
\hline Corn grain, meal & 60 \\
\hline Commercial mixed feed* & 470 \\
\hline Mineral mixture $^{\circ}$ & 7 \\
\hline \multicolumn{2}{|l|}{ Chemical composition } \\
\hline $\mathrm{CP}$ & 155 \\
\hline NDF & 442 \\
\hline $\mathrm{EE}$ & 37 \\
\hline Ash & 96 \\
\hline \multicolumn{2}{|c|}{ 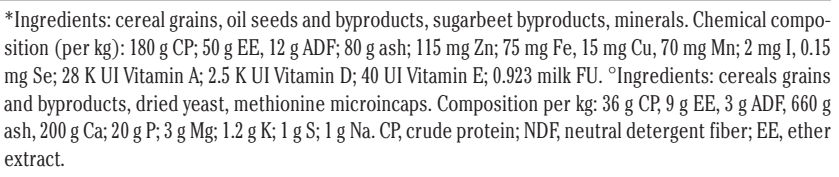 } \\
\hline
\end{tabular}

Table 2. Main experimental conditions.

\begin{tabular}{|c|c|c|c|c|c|c|c|c|}
\hline Process stage & Fermentation & Microorganism & $\begin{array}{c}\text { Process } \\
\text { temperature }\left({ }^{\circ} \mathrm{C}\right)\end{array}$ & $\begin{array}{l}\text { Lab scale } \\
\text { (L) }\end{array}$ & $\begin{array}{l}\text { Pilot plant } \\
\text { (L) }\end{array}$ & $\begin{array}{l}\text { Type of } \\
\text { feeding }\end{array}$ & $\begin{array}{l}\text { Biomass } \\
\text { recovery }\end{array}$ & WPC \\
\hline 1 & Ethanol & K marxianus Y102 & 28 & 20 & $200-2000$ & Fed-batch & Yes & Yes \\
\hline 2 & Acetic acid & A aceti DSM-3508 & 32 & 20 & $200-2000$ & Fed-batch & No & No \\
\hline
\end{tabular}

WPC, whey protein concentrate. 
Cows were milked twice daily; at the scheduled days, individual daily milk yield was recorded and sampled (Westfalia meter and sampler, Napperville, IL, USA). Throughout the experiment, dry matter intake $\left(\mathrm{kg}_{\text {group }}{ }^{-1}\right.$ ) was evaluated weekly as difference between TMR offered to the experimental groups and residuals collected $24 \mathrm{~h}$ later from the feeding alley. At the scheduled days, blood samples were collected (h. 8:00 a.m.) from jugular vein by vacutainer (Venoject, Terumo Italia s.r.l., Rome, Italy); samples were immediately centrifuged at $3000 \mathrm{rpm}$ for $10 \mathrm{~min}$ and the recovered plasma was stored at $-20^{\circ} \mathrm{C}$ for analyses described later.

\section{Analytical procedures}

Biomass was estimated by measuring turbidity in a spectrophotometer (Cary 1E, Varian, Cary, NC, USA) at $620 \mathrm{~nm}$ and relating the readings to a calibration curve of $g$ dry weight biomass $\mathrm{L}^{-1}$ as described by others. $^{25}$

To examine the production of acetic acid, ethanol and the consumption of lactose in samples during fermentation, commercially available enzymatic kits were used (Boehringer, Mannheim, Germany).

The total amounts of sugar utilization, ethanol and biomass formation during each cycle of experiments were calculated as described by Ozmihchi and Kargi. ${ }^{6}$ Total COD assays were performed according to the procedures described in the Standard Methods for Examination of water and wastewater. ${ }^{21}$

In the feeding trial, both TMR and refusal samples were analyzed for chemical composition according to the Association of Official Analytical Chemists ${ }^{26}$ and particle size of pre-dried $\left(65^{\circ} \mathrm{C}\right.$ until constant weight) samples by dry-sieving. An automatic shaking vibroscreen particle separator with nutational movements (EFJ Shaking circular vibroscreen, Erimaki, Paderno Dugnano, Italy) was equipped with two sieves (diameter stainless sieves and pan, $600 \mathrm{~mm}$ ) arranged in descending mesh size, $19 \mathrm{~mm}$ (i.e. coarse dried particles) and $8 \mathrm{~mm}$ (i.e. medium dried particles), and a pan on the bottom (i.e. fine dry matter particles); each sieving lasted $5 \mathrm{~min}$. Results from this activity have been summarized as selection index of coarse, medium and fine particles, as the ratio between percentage of particle size in residuals and TRM, according to Berzaghi et al. ${ }^{27}$ Efficiency in dairy cows implies efficiency in the rumen, where dietary ingredients affect physically the microbiota activities so that the balanced intake of ration ingredients for dairy cows should minimize the refuse of coarse, less palatable dietary particles.

Individual milk samples were analyzed according to official methods $^{28}$ by IR (Milkoscan 133B, Foss Electric, Denmark) for fat, protein, casein, milk urea, lactose and solids not fat; $\mathrm{Na}$ and $\mathrm{K}$ were measured by flame photometer (Digiflame Compact, GDV, Rome, Italy), chlorides by potentiometric methods. Titratable acidity and $\mathrm{pH}$ were measured by an automatic titrator Craison, density and milk freezing point were measured by IR (Milkoscan 133B, Foss, Hillerød, Denmark). Milk hygiene and health status of udder were evaluated by both total bacteria count (Bactoscan 4000, Foss) and somatic cells count (Fossmatic 90 , Foss).

Cheese making properties of individual milk samples were also evaluated at $\mathrm{d} 35$; rennet clotting time $\left(\mathrm{r}_{\mathrm{min}}\right)$, curd-firming time $\left(\mathrm{K}_{20}\right)$ and gel firmness $\left(\mathrm{a}_{30}\right)$ were determined by thromboelastograph Formagraph (Foss).

The plasma levels of glucose, triglycerides, total cholesterol, urea, albumin, total protein and creatinine were evaluated by colorimetric kits (Biotecnica Instruments, Rome, Italy).

\section{Statistical analyses}

Microbiological data on wheynegar were compared statistically by Tukey's $t$ test with SPSS 11.5 (SPSS for windows, Version 11.5, Chicago, IL, USA). Statistical analyses on milk yield and composition, and blood parameters were conducted using the general linear models procedure (SPSS 11.5) according to a factorial model (treatment and period) also considering the covariates DIM and data at d0. Dietary characteristics were as well processed by analysis of variance (treatment and sieve mesh size). Significance was declared at $\mathrm{P}<0.05$ and differences among means with $0.05<\mathrm{P}<0.10$ were accepted as representing tendencies to differences.

\section{Results}

\section{Identification of yeast strains}

In our search, 113 different yeast strains capable of lactose fermentation from cheese whey were isolated. However, the isolated yeasts showed poor ability to sporificate (33.3\% of total); more than half (56\%) belonged to the Candida species (Candida sp. and Candida kefyr), the rest to Kluyveromyces strains. Among those able to sporificate, we found 63 (re-called Y51-Y113) able to ferment lactose. Of these 63 strains, Kluyveromyces bulgaricus was the dominant species with 20 isolates, followed by Kluyveromyces lactis (17 species) and finally Candida kefyr and Kluyveromyces marxianus (13 strains). Two Kluyveromyces isolated strains (K. bulgaricus $\mathrm{Y} 87$ and $K$. marxianus Y102) able to use glucose, galactose, sucrose and raffinose, but not in maltose and trehalose, were the most potent yeasts in fermenting lactose. More characteristic tests in K. marxianus Y102 are positive inuline, D-xylose, glycerol and L-lysine assimilation, but negative L-arabinose, L-rhamnose, and inositol; no assimilation of nitrogen compounds (nitrate), growth at $37^{\circ} \mathrm{C}$, and growth absent in $50 \%$ glucose were observed.

\section{Alcoholic fermentation and acetic fermentation in lab- oratory and plant bioreactor}

The concentration of residual lactose decreased during the alcoholic fermentation with Kluyveromyces marxianus as inoculum (Stage 1), while an increase in ethanol production has been observed. The maximum production appears in correspondence with the loading-unloading cycles of $48 \mathrm{~h}$, during which ethanol production ranged from 10.50 to $13.04 \mathrm{~g} \mathrm{~L}^{-1}$. Throughout the 11 days of the alcoholic fermentation, the process appeared quite stable. The stability of the fermentative trials, and the increased ethanol production when operated with biomass recycling, have been observed up to the $23^{\text {rd }}$ day (Figure 1). Ethanol production ranged from 9.52 to $18.54 \mathrm{~g} \mathrm{~L}^{-1}$. On the other hand, when the process was operated without biomass recycling (since $24^{\text {th }}$ day, see arrow) the stability of the fermentative trials showed a strong decrease, even if we recorded the highest alcoholic yield and lower lactose content residues. The system adopted for yeast biomass recycling was a not sophisticated solution in the recovery of crude cell biomass, and appear to guarantee an acceptable degree of damage of cells during the procedure of recycling. In the fermentation trials, $\mathrm{pH}$ values declined at 3.9 , as consequence of the increase in acetic acid production. From the initial $5400 \mathrm{~L}$ cheese whey, about $4000 \mathrm{~L}$ of wheynegar, with an average acetic acid content of $11.55 \mathrm{~g} \mathrm{~L}^{-1}$, were obtained at the end of the acetic fermentations. Table 4 shows the main parameters and products in the scale-up of the alcoholic and acetic fermentations on cheese whey. The data from these plants confirm partially the preliminary laboratory scale results where the biomass recovery of sweet whey $\left(3.4 \mathrm{~g} \mathrm{~L}^{-1}\right)$ was obtained, with a final total recovery of WPC of $1.35 \mathrm{~kg} \mathrm{~L}^{-1}$. A slight increase in ethanol and acetic acid (12-14 $\mathrm{g} \mathrm{L}^{-1}$ and $11.55 \mathrm{~g} \mathrm{~L}^{-1}$, respectively) were recorded as consequence of the scaling-up of the process. However, at large scale the re-circulation of biomass where not adopted, so the highest values were not comparable to those obtained in the lab scale. 
Table 4. Main parameters during the scale-up of the alcoholic and acetic fermentations on cheese whey.

\begin{tabular}{|c|c|c|c|c|c|c|c|}
\hline $\begin{array}{l}\text { Bioreactor } \\
\text { (process) }\end{array}$ & $\begin{array}{l}\text { Alcoholic } \\
\text { end-product } \\
\text { (L) }\end{array}$ & $\begin{array}{l}\text { Ethanol } \\
\left(g \times L^{-1}\right)\end{array}$ & $\begin{array}{l}\text { Ethanol productivity } \\
\qquad\left(\mathrm{g} \times \mathrm{L}-1 \times \mathrm{h}^{-1}\right)\end{array}$ & $\begin{array}{c}\text { Total biomass } \\
\text { recovery } \\
\text { (kg) }\end{array}$ & $\begin{array}{l}\text { Total WPC } \\
\text { (kg) }\end{array}$ & $\begin{array}{l}\text { Acetic acid } \\
\text { end-product } \\
\text { (L) }\end{array}$ & $\begin{array}{l}\text { Acetic acid } \\
\text { content } \\
\left(\mathrm{g} \times \mathrm{L}^{-1}\right)\end{array}$ \\
\hline $20 \mathrm{~L}$ (batch) & 18 & 11.92 & 0.50 & 0.95 & 0.08 & 15 & 8.7 \\
\hline $200 \mathrm{~L}$ (batch) & 180 & 12.57 & 0.52 & 8.58 & 0.58 & 150 & 9.5 \\
\hline $2000 \mathrm{~L}$ (fed-batch) & 4200 & $13.4 \mathrm{~N} 8$ & 0.56 & 200 & 13.45 & 4000 & 11.55 \\
\hline
\end{tabular}

WPC, whey protein concentrate.

\section{Acetic end-product stability}

The microbiological quality of acetic acid end-products was satisfactory, as indicated by the microbiological analyses conducted at the end of experiments. The mean population counts of total viable count, yeasts, lactic acid bacteria were 6.97, 3.79 and $4.02 \log \mathrm{CFU} \mathrm{mL}^{-1}$, respectively, while complete absence of fecal coliforms microorganisms were noted. Moreover, the shelf-life of acetic acid end-products at the 3 different storage temperatures (room temperature, $4^{\circ} \mathrm{C}$ and $28^{\circ} \mathrm{C}$ ) for 28 days, showed that wheynegar was stable and no alteration in color and odors occurred.

\section{Total chemical oxygen demand removal}

The alcoholic and acetic fermentations of the cheese whey indicate a further advantage of the reduction/abatement of this by-product's polluting load. In fact, compared to the initial values, the total COD was reduced $47 \%$ for the alcoholic fermentation $\left(30.9 \mathrm{~g} \mathrm{~L}^{-1}\right)$ and $50 \%$ for the acetic $\left(28.8 \mathrm{~g} \mathrm{~L}^{-1}\right)$.

\section{Feeding trial}

The animals of $\mathrm{W}$ group quickly adapted to the dietary treatment and their body condition scores was not significantly affected by wheynegar administration [W: 2.90, C: 2.80, standard error mean (SEM): 0.07].

The dietary treatment did not affect the voluntary dry matter intake (W: $22.45 \mathrm{~kg}$, C: $21.12 \mathrm{~kg}$, SEM $0.8 \mathrm{~kg}$ ). However, chemical composition of TMRs and feed residuals (Table 5) shows a higher NDF content of C residuals. Although wheynegar administration in TMR did not significantly affect the selection indices of coarse ( $>19 \mathrm{~mm})$, medium $(8-19 \mathrm{~mm})$ and fine $(<8 \mathrm{~mm})$ dietary particles, Figure 2 also shows a tendential $(\mathrm{P}=0.089)$ higher intake, or lower refuse, of coarse particles from $\mathrm{W}$ group. Milk yield was not affected by the dietary treatment (Table 6); milk chemical components composition as well did not differ between the two groups except for the significant lower urea content observed in group W. The investigated physicochemical characteristics of milk were statistically unaffected by the wheynegar administration; however it has to be noted that milk titratable acidity was found tendentially higher compared to group C (Table 6).

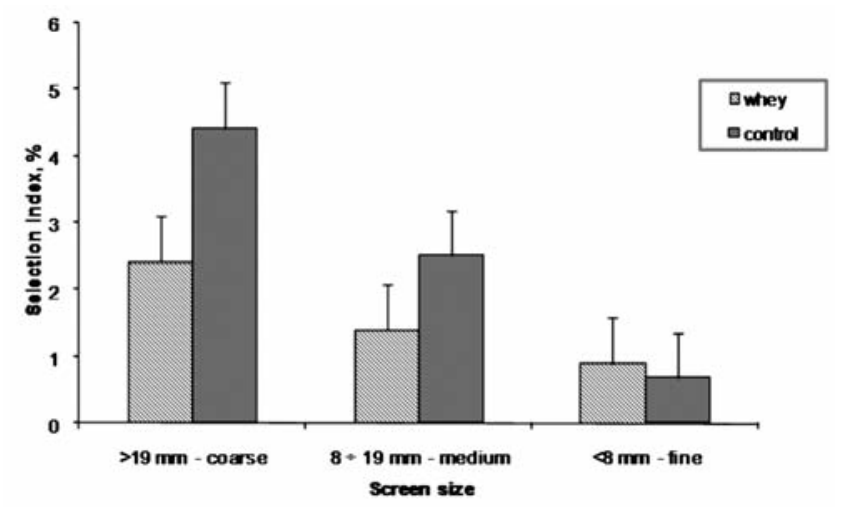

Figure 2. Selection indices of dietary particles by size.
Both absolute and relative content of milk casein did not vary significantly, nor the investigated bulk cheese making properties (Table 6) were affected by the dietary treatments. Wheynegar as diet ingredient did not statistically influence the milk mineral composition (Table 6)

Table 5. Total mixed rations and residuals after $24 \mathrm{~h}$ : chemical composition (g/kg dry matter).

\begin{tabular}{lcccc} 
Parameter & \multicolumn{2}{c}{ Groups } & & \\
& W & C & SEM & P \\
DM TMR & 582.0 & 620.7 & 26.3 & 0.129 \\
DM residuals & 516.0 & 548.3 & 26.3 & 0.411 \\
\hline CP TMR & 147.3 & 149.0 & 7.2 & 0.875 \\
CP residuals & 132.0 & 121.0 & 7.2 & 0.313 \\
\hline Ash TMR & 94.3 & 89.0 & 0,51 & 0.482 \\
Ash residuals & 99.0 & 88.6 & 0,51 & 0.195 \\
\hline NDF TMR & 457.0 & 466.3 & 18.7 & 0.733 \\
NDF residuals & 505.0 & 559.3 & 18.7 & $<0.05$ \\
\hline
\end{tabular}

SEM, standard error mean; DM, dry matter; TMR, total mixed rations; CP, crude protein; NDF, neutral detergent fiber.

Table 6. Effects of dietary treatment on milk yield, composition and physicochemical characteristics.

\begin{tabular}{|c|c|c|c|c|}
\hline Parameter & $\begin{array}{l}\text { Groups } \\
\text { W }\end{array}$ & C & SEM & $\mathbf{P}$ \\
\hline Milk yield $\left({\left.\mathrm{kg} \times \mathrm{d}^{-1}\right)}^{-1}\right.$ & 21.98 & 21.35 & 0.82 & 0.601 \\
\hline Fat $(g \times 100$ g-1of milk) & 3.89 & 3.80 & 0.12 & 0.608 \\
\hline Protein & 3.49 & 3.39 & 0.04 & 0.194 \\
\hline Casein $\left(\mathrm{g} \times 100 \mathrm{~mL}^{-1}\right.$ of milk) & 2.60 & 2.48 & 0.05 & 0.144 \\
\hline Casein (\% protein) & 74.17 & 74.08 & 0.42 & 0.892 \\
\hline Urea (mg×100 $\mathrm{g}^{-1}$ of milk) & 23.84 & 28.95 & 0.98 & $<0.01$ \\
\hline Lactose $\left(\mathrm{g} \times 100 \mathrm{~mL}^{-1}\right.$ of milk $)$ & 4.80 & 4.80 & 0.03 & 0.976 \\
\hline Solids not fat & 9.00 & 8.88 & 0.05 & 0.142 \\
\hline SCC $\left(\log\right.$ CFU $\left.\times 100 \mathrm{~mL}^{-1}\right)$ & 5.45 & 5.45 & 0.14 & 0.954 \\
\hline TBC & 4.21 & 4.28 & 0.07 & 0.539 \\
\hline $\mathrm{Na}\left(\mathrm{mg} \times 100 \mathrm{~mL}^{-1}\right.$ of milk$)$ & 46.36 & 41.34 & 1.75 & 0.067 \\
\hline K & 140.72 & 137.85 & 0.41 & 0.409 \\
\hline $\mathrm{NaCl}$ & 0.16 & 0.16 & 0.01 & 0.705 \\
\hline $\mathrm{pH}$ & 6.78 & 6.78 & 0.02 & 0.899 \\
\hline \multicolumn{2}{|c|}{ Titratable acidity ( $\left.{ }^{\circ} \mathrm{SH} \times 100 \mathrm{~mL}^{-1}\right) 6.46$} & 6.04 & 0.19 & 0.096 \\
\hline Density ( $g \times L-1)$ & 1031.8 & 1031.5 & 0.27 & 0.439 \\
\hline $\operatorname{MFP}\left({ }^{\circ} \mathrm{C}\right)$ & -0.53 & -0.53 & 0.002 & 0.306 \\
\hline $\mathrm{r}(\min )$ & 19.20 & 19.23 & 0.71 & 0.983 \\
\hline $\mathrm{K} 20$ (min) & 2.88 & 2.97 & 0.43 & 0.879 \\
\hline a30 (mm) & 34.46 & 30.76 & 2.16 & 0.291 \\
\hline
\end{tabular}

SEM, standard error mean; SCC, somatic cell count; CFU, colony forming units; TBC, total bacteria count; MFP, milk freezing point; r, rennet clotting time; K20, curd-firming time; a30, gel firmness. 
but a tendential increase $(\mathrm{P}=0.067)$ in milk sodium content should be noted in group W. As far as the nutritional status of dairy cows is concerned, plasma metabolites (Table 7) were not statistically influenced by wheynegar administration, even though group $\mathrm{W}$ evidenced a higher albumin content than group $\mathrm{C}(\mathrm{P}=0.08)$.

\section{Discussion and Conclusions}

The necessity to isolate and select yeast was researched by many investigators to ascertain if those yeast strains were suitable to high ethanol production. Other studies reveal that $K$. lactis, $K$. marxianus var. marxianus and its anamorph, $C$. kefyr, are the most predominant and important yeast species in milk. ${ }^{29}$ With regard to the other yeast strains isolated and identified in this study, $K$. marxianus and $K$. lactis are employed in different biotechnology applications. ${ }^{13,30,31}$ Indeed, $K$. marxianus is the most widely studied yeast for the production of yeast biomass from whey ${ }^{1}$ and large-scale processes for Kluyveromyces biomass production have been operating for several years. ${ }^{32}$ Our data about yeast selection, confirm that $K$. marxianus is the most predominant and important yeasts species isolated in this study.

The role of $\mathrm{pH}$ in the stability of the process is one of the most important parameters in alcoholic fermentation. In stage 1, the $\mathrm{pH}$ values of whey permeate during the 11 days of alcoholic fermentation show regular courses of intervals (about $48 \mathrm{~h}$ ), closely corresponding to the loading-unloading phases of fresh substrate. In fact, the time course of processes of feeding, adopting a $48 \mathrm{~h}$ retention time, higher $\mathrm{pH}$ values (4.0-4.1) were recorded, coinciding with the highest alcoholic content at $48,96,144,192 \mathrm{~h}$ of fermentations. On the contrary, after each fresh permeate addition to the bioreactor the pHs values dropped up to 3.80 3.85 , due to the additional lactic acid resulting from the previous lactose lactic fermentation. Santos et al ${ }^{33}$ reported that maintaining the $\mathrm{pH}$ between 4.0 and 5.0 is very essential for the growth and survival of $K$. marxianus. Yeast cells use lactose for energy and growth. Theoretically, $100 \mathrm{~g}$ of lactose can be expected to yield $47.3 \mathrm{~g}$ of ethanol and $9.23 \mathrm{~g}$ of cells. ${ }^{34}$ The initial lactose value of the whey used in this study was $23.7 \mathrm{~g} \mathrm{~L}^{-1}$.

In the case of the $20 \mathrm{~L}$ bioreactor, the results verified the observations at lab-scale encouraging experiments at higher scale. In the 200 $\mathrm{L}$ bioreactor the concentrations obtained were similar to those of lab scale-experiments, with a ethanol productivity of $0.50 \mathrm{~g} \mathrm{~L}^{-1} \mathrm{~h}^{-1}$ for the $20 \mathrm{~L}$ bioreactor and 0.52 for the $200 \mathrm{~L}$ bioreactor and yield of $0.59 \mathrm{~g} \mathrm{~g}^{-1}$ showing potential industrial application. The increased fermentation times may be attributed to the lower biomass concentrations, since the biomass needed for the first fermentation batch was produced aerobically into the bioreactor, but from that point the biomass of each anaerobic fermentation was used for the next fermentation batch.

Likewise, three fed-batch fermentations were carried out in the industrial-scale bioreactor of $1800 \mathrm{~L}$. After the end of fermentation, residual lactose concentrations were about $2.35 \mathrm{~g} \mathrm{~L}^{-1}$, therefore conversion was not higher than $90 \%$. Fermentation times were similar, while ethanol concentrations $(\sim 1.65 \%, v / v)$ were a little higher than those obtained in the $20 \mathrm{~L}$ bioreactor $(1.45 \%, \mathrm{v} / \mathrm{v})$, but consistent with those recorded in the $200 \mathrm{~L}$ bioreactor. The total biomass produced was about $2.2 \mathrm{~g} \mathrm{~L}^{-1}$ of cheese whey. The maximum ethanol production achieved in feed-batch with biomass recycling was $0.78 \mathrm{~g} \mathrm{~L}^{-1} / \mathrm{h}$, corresponding to an ethanol yield of $0.65 \mathrm{~g} \mathrm{~g}^{-1}$; these values are higher than the $0.47 \mathrm{~g} \mathrm{~g}^{-1}$ previously reported by Geng et al. ${ }^{35}$ who did not recycle the biomass. The use of the biomass during the recycling guaranteed a suitable source of nitrogen and bacterial inoculum, according to Kisaalita $e t$ $a l{ }^{36}$ That is confirmed by the highest values obtained only in the lab
Table 7. Plasma metabolites as affected by dietary treatments.

\begin{tabular}{lcccc} 
Parameter & $\begin{array}{c}\text { Groups } \\
\text { W }\end{array}$ & C & SEM & P \\
Glucose $\left(\mathrm{mmol} \times \mathrm{L}^{-1}\right)$ & 3.37 & 3.36 & 0.07 & 0.954 \\
Cholesterol $\left(\mathrm{mmol} \times \mathrm{L}^{-1}\right)$ & 5.33 & 5.66 & 0.17 & 0.191 \\
\hline Triglycerides $\left(\mathrm{mmol} \times \mathrm{L}^{-1}\right)$ & 0.139 & 0.143 & 0.09 & 0.796 \\
Total protein $\left(g \times \mathrm{L}^{-1} \mathrm{l}\right)$ & 81.63 & 81.81 & 1.57 & 0.952 \\
\hline Albumin $\left(\mathrm{g} \times \mathrm{L}^{-1}\right)$ & 25.46 & 24.54 & 0.35 & 0.080 \\
Creatinine $(\mu \mathrm{M})$ & 103.41 & 104.35 & 2.46 & 0.799 \\
\hline
\end{tabular}

SEM, standard error mean.

scale $\left(18.54 \mathrm{~g} \mathrm{~L}^{-1}\right)$. In stage 2 , the acetic acid production in the industrial-scale bioreactor was $11.55 \mathrm{~g} \mathrm{~L}^{-1}$ and the total yield $\left(\mathrm{Y}_{\text {AceticEthanol }}\right)$ was $0.88 \mathrm{~g} \mathrm{~g}^{-1}$; acetic acid productivity was found $0.2 \mathrm{~g} \mathrm{l}^{-1}$ per hour, a value lower than that of $0.4 \mathrm{~g} \mathrm{~L}^{-1} \mathrm{~h}^{-1}$ reported in the literature, ${ }^{25}$ and the acetic acid conversion efficiency (experimental yield/theoretical yield) was $88.9 \%$. Data on wheynegar shelf-life during the time show that the acetified whey permeate did not change in the acetic acid content under room conditions, confirming a constant level through to the end of the 28-days storage. These data suggest that its storage at environmental temperature can be maintained for sufficiently long and suitable times prior its use, without additional costs for proper refrigeration and transport.

The experiment has provided relevant important data that confirm the feasibility of transferring the procedure to real scale plants where there is the possibility of evaluating large daily permeate quantities. By combining both fermentations, the difference between the initial and final values of the total COD is likely due to the consumption of large biodegradable lactose by yeast, with a total COD abatement of $75 \%$. Wheynegar was offered to dairy cows in mid-late lactation fed a hay based total mixed ration, which is common in traditional dairy farms of centre-south Italy. The dietary treatment did not affect dry matter intake however, a more balanced intake of effective nutrients is suggested for cows fed wheynegar than control cows by both chemical composition and particle size distribution of feed refusals (after $24 \mathrm{~h}$ administration TMR). The refusal of coarser dietary particles in group $\mathrm{C}$ is in fact consistent with the higher NDF content of group $\mathrm{C}$ feed residuals and could be explained by the low quality (mature and mouldy) of the meadow hay in both rations but tendentially masked by the palatable effect of wheynegar in group $\mathrm{W}$.

The nutritional status of dairy cows was not influenced by the dietary treatments and in both groups plasma constituents were found within the normality range, according to Kaneko et al. ${ }^{37}$

As far as milk production is concerned, all the parameters studied in milk were within the CE legal limits. Both milk yield and chemical composition were not affected by the wheynegar administration, except for the lower milk urea content observed. Besides the hypothesized palatable effect on intake of low quality forages, wheynegar could have a positive influence on growth and performances of rumen microorganisms, favoring a better use of nitrogen so that microbial efficiency could be improved. ${ }^{20}$ The tendential increase of plasma albumin observed in cows receiving wheynegar could confirm this hypothesis, as albumin is a major storage reservoir of proteins and transporter of amino acids, according to literature. ${ }^{37}$ However it has to be noted that milk casein content was not influenced by wheynegar administration and the investigated cheese-making properties of milk are generally considered good or fairly good in both experimental groups.

The tendency to a higher Na content of milk in group $\mathrm{W}$ could be related to Na content of wheynegar; however, on this regard it has to be noted that the $\mathrm{Na}$ intake was within the levels recommended for dairy cattle. $^{38}$ The investigated physicochemical characteristics were statis- 
tically unaffected by the wheynegar administration, even though the tendential higher titratable acidity could be related to the lower milk urea content. Taken together the results suggest the feasibility of the biotechnological exploitation of cheese whey using opportunely selected yeasts (Kluyveromyces marxianus Y102) for ethanol and acetic fermentations. The fermentations are stable over time and the fermented product (acetic mixer) has a long shelf life.

The research points out that cheese whey could provide a valuable resource for the production of usable and profitable derived products to be recycled within the traditional dairy chain, like wheynegar. During a 35 days feeding trial, dairy cows in mid-late lactation quickly adapted to the daily administration of $10 \mathrm{~L}$ wheynegar per head. The dietary treatment did not affect the nutritional status of the animals but it positively affected the palatability of a hay based ration, contributing to a more balanced nutrients intake with positive effects on both efficiency of rumen microbiota and milk quality (lower milk urea content). The encouraging results of this pilot study need to be confirmed over entire lactation as well as under different dietary strategies. At the same time, in depth studies should clarify the economical and social costs to profits ratios of whey fermentation and wheynegar recycling within the traditional dairy chain of marginal areas.

\section{References}

1. Grba S, Tomas VS, Stanzer D, et al. Selection of yeast strain Kluyveromyces marxianus for alcohol and biomass production on whey. Chem Biochem Eng Q 2002;16:13-6.

2. Von Stocker U, Marison IW. Unconventional utilization of whey in Switzerland. In: Ghose TK, ed. Bioprocess engineering. Oxford: IRS Press; 1993. pp 342-392.

3. Roostita R, Fleet GH. Growth of yeasts in milk and associated changes to milk composition. Int J Food Microbiol 1996;31:215-9.

4. Cristiani-Urbina E, Netzahuati-Munoz AR, Manriquez-Rojas FJ, et al. Batch and fed-batch cultures for the treatment of whey with mixed yeast cultures. Process Biochem 2000;35:649-57.

5. Zafar S, Owais M, Saleemuddin M, Husain S. Batch kinetics and modelling of ethanolic fermentation of whey. Int J Food Sci Technol 2005; 40:597-604.

6. Ozmihci S, Kargi F. Continuous ethanol fermentation of cheese whey powder solution: effects of hydraulic residence time. Bioproc Biosyst Eng 2007;30:79-86.

7. Pizzichini M. Tecnologie di processo per il recupero e la valorizzazione delle componenti del siero di latte. Roma: ENEA; 2006. [In Italian]

8. Panesar PS, Kennedy JF, Gandhi DN, Bunko K. Bioutilisation of whey for lactic acid production. Food Chem 2007;105:1-14.

9. Smithers GW. Whey and whey proteins-From 'gutter-to-gold'. Int Dairy J 2008;18:695-704.

10. Ben-Hassan RM, Ghaly AE. Continuous propagation of Kluyveromyces fragilis in cheese whey for pollution potential reduction. Appl Biochem Biotechnol 1994;47:89-105.

11. Ghaly AE, Kamal M, Avery A. Influence of temperature rise on kinetic parameters during batch propagation of Kluyveromyces fragilis in cheese whey under ambient conditions. World J Microbiol Biotechnol 2003;19:741-9.

12. Ghaly AE, Kamal MA. Submerged yeast fermentation of acid cheese whey for protein production and potential pollution reduction. Water Res 2003;38:631-44.

13. Siso MIG. The biotechnology utilization of cheese whey: a review. Bioresource Technol 1996; 57:1-11.

14. Golubev WI, Golubev NW. Selection and study of potent lactose-fermenting yeasts. Appl Biochem Microbiol 2004;40:280-4.
15. Formigoni A, Piva A, Pezzi P, et al. The influence of feeding fresh liquid whey on some blood metabolites, insulin, and cecal fermentations of growing pigs. Anim Feed Sci Technol 2006;131:52-65.

16. Golombeski GL, Kalscheur KF, Hippen AR, Schingoethe DJ. Slowrelease urea and highly fermentable sugars in diets fed to lactating dairy cows. J Dairy Sci 2006;89:4395-403.

17. Preisegolaviciute-Mozuraitiene D, Malakauskas M, Liutkevicius A, et al. The effect of functional liquid whey fed to dairy cows on milk yield, composition and quality. Milchwissenschaft 2011;66:235-9.

18. Huang Y, Yang ST. Acetate production from whey lactose using coimmobilized cells of homolactic and homoacetic bacteria in a fibrousbed bioreactor. Biotechnol Bioeng 1998;60:498-507.

19. Talabardon M, Schwitzguébel JP, Péringer P, Yang ST. Acetic acid production from lactose by an anaerobic thermophilic coculture immobilized in a fibrous-bed bioreactor. Biotechnol Progr 2000;16:1008-17.

20. Van Soest PJ. Nutritional ecology of the ruminants. 2nd ed. Ithaca and London: Cornell University Press; 1994.

21. APHA. Standard methods for examination of water and wastewater. 1st ed. New York: American Public Health Association; 1998.

22. Kurtzman CP. Classification and general properties of yeasts. In: Verachtert H, De Mot R, eds. Yeast biotechnology and biocatalysis. New York: Marcel Dekker; 1990. p 1-34.

23. Kurtzmann CP, Fell JW. The yeast: A taxonomic study. Amsterdam: Elsevier; 1998.

24. INRA. Alimentation des bovins, ovins et caprins. Paris: INRA; 1988. p 471.

25. Parrondo J, Herrero M, Garcìa LA, Dìaz M. A note - Production of vinegar from whey. Acta Biotechnol 2004;17:51-61.

26. AOAC. Official methods of analysis of AOAC international. 17th ed. CITY, Maryland: Association of Official Analytical Chemists; 2000.

27. Berzaghi P, Cozzi G, Gottardo F, et al. Effetto delle dimensioni delle particelle di una dieta unifeed sul comportamento alimentare e sulla produzione di bovine da latte. Zoot Nutr Anim 2001;27:135-44. [In Italian].

28. ASPA. Metodi di analisi del latte delle principali specie di interesse zootecnico. Perugia: Università di Perugia Press; 1996.

29. Gadaga TH, Mutukumira AN, Narvhus JA. Enumeration and identification of yeasts isolated from Zimbabwean traditional fermented milk. Int Dairy J 2000;10:459-66.

30. Shan NP, Spurgeon KR, Gilmore TM. Use of dry whey and lactose hydrolysis in yogurt bases. Milk Sci Int 1993;48:494-8.

31. Fonseca GG, Heinzle E, Wittmann C, Gombert AK. The yeast Kluyveromyces marxianus and its biotechnological potential. Appl Microbiol Biotechnol 2008;79:339-54.

32. Litchfield JH. Single-cell proteins. Science 1983;219:740-76.

33. Santos A, Ladero M, García-Ochoa F. Kinetic modeling of lactose hydrolysis by a $\beta$-galactosidase from Kluyveromices fragilis. Enzyme Microb Tech 1998; 22:558-67.

34. Ghaly AE, El Taweel AA. Kinetics of batch production of ethanol from cheese whey. Biomass Bioenerg 1994;6:465-78.

35. Geng J, Song HS, Yuan J, Ramkrishna D. On enhancing productivity of bioethanol with multiple species. Biotechnol Bioeng 2012; 109:1508-17.

36. Kisaalita WS, Lo KV, Pinder KL. Influence of whey protein on continuous acidogenic degradation of lactose. Biotechnol Bioeng 1990;36:642-6.

37. Kaneko J, Harvey J, Bruss M. Clinical biochemistry of domestic animals. 6th ed. Amsterdam: Elsevier; 2008.

38. NRC. Nutrient requirements of dairy cattle. 7th ed. Washington: National Academy Press; 2001. 